\title{
Local networks, stakeholder dynamics and sustainability in tourism. Opportunities and limits in the light of stakeholder theory and SNA ${ }^{1}$
}

\author{
Umberto Martini - Federica Buffa
}

\begin{abstract}
Purpose of the paper: Given the importance of relationships between territorial actors and their ability to make collective decisions in order to ensure the sustainable development of tourism, this paper suggests social network analysis (SNA) as an appropriate method to explain the dynamics of interpersonal relationships in tourist areas.

Methodology: The stakeholder map was reconstructed by using stakeholder theory in conjunction with the identification of actors through snowball sampling. The most important stakeholders were identified by adopting the in-degree centrality indicator referred to the weighted adjacency matrix (quantitative) and the role played by stakeholders (qualitative). The in-degree network centralization indicator showed the distribution of centrality between the nodes of the network.

Findings: SNA enriches the reading of multi-stakeholder relationships in nonhierarchical territorial contexts; it picks up on the evolving dynamic of networks and the relative weights of the decision makers within them, providing a more comprehensive and convincing interpretation than does the stakeholder approach alone.

Research limits: exploratory research was undertaken in order to focus on analytical tools and the general theoretical framework.

Practical implications: the reconstruction of the networks and the interpretation of the relationships provide a sounder basis for the definition of strategies and of instruments that are employed to facilitate processes of participative governance in accordance with principles of sustainability.

Originality of the paper: few applications of SNA to tourism have so far appeared in the literature. However, the results derived from SNA can open new scenarios in destination management since, as well as demonstrating the existence of relationships, they also classify and prioritize them.
\end{abstract}

Key words: tourism sustainability; destination management; stakeholder approach; social network analysis

1 This paper was co-authored by U. Martini and F. Buffa. However, sections 1 and 2 can be attributed to U. Martini, 3 and 4 to F. Buffa. The conclusions are shared. 
sinergie Vol. 33, N. 96, 2015

\section{The relevance of sustainability in the tourism industry: a literature review from the perspective of destination management}

In the last twenty years, due to several global macro-factors, the tourism industry has been subject to profound change (Dwyer et al., 2009; Weaver, 2011). In this new landscape, many analyses, starting with that of the World Tourism Organization (UNWTO-UNEP, 2005; UNWTO, 2011), have focused on the need to rethink tourism development models in the light of the sustainability paradigm. There has been increasing criticism of the impact of tourism on the environment, on local communities and on the distribution of wealth; having first called the positive impacts of tourism on an area's wellbeing and economic development into question (Bramwell and Lane, 1993), research into new principles upon which to base more desirable development models is now being emphasized (Hardy et al., 2002; Ryan, 2002). The economic importance of tourism and its numerous social and environmental impacts (UNTWO, 2011) require the careful evaluation of these impacts in the medium and long term on local, regional and national development. If tourism development is to be sustainable it must be rooted in an holistic approach: taking into account an area's political, socio-economic and ecological context; future impacts (generational equity) and, given international tourism flows, its effects on other countries (Sharpley, 2000).

Tourism takes place in settings created by a combination of the natural environment, the human-made environment and the socio-economic environment, each of which provides specific resources. The decisions made in relation to the use and transformation of these resources by the tourist industry must therefore allow for the management of three capital assets which are not (entirely) interchangeable: natural capital, economic capital and socio-cultural capital, and whose consumption is often irreversible (Turner et al., 1994; Hunter, 1997; Garrod and Fyall, 1998).

Sustainable tourism development tries to balance the economic returns of tourism with the conservation of the non-renewable resources consumed by the tourist industry (Inskeep, 1991; Swarbrooke, 1999). The impact of tourism on the natural environment in which it takes place is indeed considerable in terms of: land use; the need for infrastructure and facilities which change the landscape forever; the rival use requirements of available resources (land, labour, capital); the need for goods and services (and for the corresponding systems of production) and unavoidable intercultural encounters. Consequently, when an area decides to develop its tourist industry, the whole local development model is affected and the area has to make choices as to how it assigns resources, what its production goals are, and the extent to which social and business changes involving the local population are desirable. Tourism's sustainability is therefore dependent on the creation of a balanced relationship between the needs of all the stakeholders involved (Cronin, 1990; Cater, 1993; Lane, 1994; Hunter, 1997). Specifically, the following conditions must be met:

- tourists' expectations and requirements must be fulfilled;

- private operators in the various tourism fields must be able to achieve their economic goals; 
- local institutions and public bodies must be able to meet their chosen development aims;

- the social and professional needs of local residents must be met, and their quality of life improved;

- the areas capital (in particular natural and socio-cultural) must be preserved and fostered.

Sustainable tourism development therefore relies on collective decisionmaking around the transformation of - particularly natural and economic - capital resources. It is this which allows management and governance issues to be emphasized within tourist areas. The complex web of relations and interests involved generate some critical factors, which require careful analysis:

1. typically, the shape of communities within tourist areas increases the incidence of conflicts around decision-making, owing to the lack of shared visions or objectives on the part of the various actors involved;

2. the relationships between the different actors are not solely economic; they are also shaped by the political and social context of the area;

3. local actors belong to various macro-categories - sector, field of activity, type of representation. These macro-categories are also, however, highly fragmented and consequently tend to further undermine any positions held, or objectives intended.

It is crucial, in contexts such as these, from a strategic managerial perspective, to investigate and understand the network of relationships between the various actors, and to ascertain the nature and strength of their connections. The reconstruction of a network and the analysis of the relationships within it allow both the identification and evaluation of the key players involved in the governance of the destination, and an analysis of the decision-making processes that are followed in the areas tourism development.

This paper presents a methodology which identifies methods, tools and indicators that may be used to investigate structural characteristics and relational dynamics within multi-stakeholder territorial contexts. Assuming that community-type destinations are formed by networks of actors, resources and activities (cf section 2), the methodology here proposed evaluates the qualitative approach of stakeholder theory and integrates it with the quantitative social network analysis (SNA) approach. The contributions of stakeholder theory and SNA are focused on:

- stakeholder theory, with particular reference to the "stakeholder definition and salience" research strand (Laplume et al., 2008);

- social network analysis, focusing on the methods, tools and indicators aimed at investigating and understanding the nodes and connections which develop within the network.

The paper is divided into five sections. The complexity of multistakeholder territorial systems clearly emerges from the analysis of the distinctive elements of management for sustainable tourism (section 2). The methodological approach used to identify the nodes and connections within a network is described in section 3. Using the case method, the (methodological and empirical) results observed through the application of this method are analysed in section 4. The conclusion highlights
Umberto Martini

Federica Buffa Local networks, stakeholder dynamics and

sustain

sustainability in tourism.

Opportunities and limits
in the light of stakeholder theory and SNA 
sinergie Vol. 33, N. 96, 2015

the possibilities and limitations of the approach and the managerial implications for the sustainable development of these territorial systems.

\section{Management for sustainable tourism: governance, conflicts and participatory decision-making}

By the beginning of the 1990s it was already clear that the concept of sustainable tourism had to be linked to the areas of strategic planning and management (Hughes, 1995; Hunter, 1995). From the perspective of business economics it is interesting to see whether or not sustainability, in relation to tourism, can really be translated into a territory's governance values and business management. The approach to sustainability must therefore be applied at the managerial level, identifying strategies which give direction to business, organizational and institutional behaviours, and becoming an integral part of the management of a territory's tourist destinations (Gladwin et al., 1995).

Starting from the extremely broad debate about the competitiveness of destinations (Crouch, 2007; Mazanec et al., 2007), the approach to sustainability has been strategic, based on the understanding that tourism management must combine the development requirements of the offer (and therefore those of its services, facilities and infrastructure) with the preservation of both the natural environment and social equilibrium. The requirements of sustainability thus become preconditions for a destination's competitiveness (Middleton and Hawkins, 1998; Mihalic, 2000; Ritchie and Crouch, 2005): strategic management entails the adoption of a long term view and the use of coherent managerial approaches is essential in order to maintain balanced tourist flows, evaluating their impact on natural and socio-cultural capital.

Sustainability must be pursued through the adoption of a tourism policy (Ritchie and Crouch, 2000), given the importance of the public sector (at the state, regional and municipal level) in tourism development (Hall, 1994, 1999, 2011; Hall and Jenkins, 1995; Bramwell and Lane, 2000). Tourism management must thus be integrated into the process of area planning and be included within a territory's legislative framework (Hunter and Green, 1995; Hjalager, 1996; Ahn et al., 2002).

The existence of a public/private dialectic, the presence of numerous actors operating outside any hierarchical context, and the close-knit nature of local communities, have combined to prompt most scholars to read the collaborative relationships which exist among the different actors in tourist destinations in terms of network theory (Jamal and Getz, 1995; Bramwell and Sharman, 1999; Dredge, 2006; Baggio et al., 2010a; Baggio et al., 2010b); Beritelli, 2011).

Tourist destinations can, in fact, be analysed as a network of relationships between stakeholders, whose power and influence varies according to the resources they control, their role/position and their interests (Robson and Robson, 1996; Reed, 1997; Sautter and Leisen, 1999; Sheenan and Ritchie, 2005). Strategic decisional processes in such 
contexts must be capable of withstanding conflict and accommodating stakeholders' various expectations.

The problems around coordination and collaboration bring to mind the concepts of focal firm and the opportunities offered by inter-company relationships. The solutions adopted by small and medium enterprises within industrial districts cannot, however, be directly applied to actors involved in tourist destinations.

Researchers in the field of tourism management have therefore sought solutions which take the specificities of tourism into account. They identify, on the one hand, territorial meta-management organizations that are able to coordinate the activities of all the businesses present in the area and, on the other hand, coordination mechanisms which incentivize and support collaboration between businesses.

Decisional processes based on stakeholder negotiation and participation (Getz, 1986; Haywood, 1988; Simmons, 1994; Reid et al., 2004) are particularly appropriate. Development planning based on participatory decisional processes seems, in fact, to foster responsibility and burden sharing among the various territorial actors. An important factor may be the involvement of people who consider not only the economic perspective but - being deeply knowledgeable about both the resources available in, and the needs of, an area - are also able to articulate the importance of reducing the potentially negative impacts of tourism (Middleton and Hawkins, 1998; Milne and Ateljevic, 2001).

The numbers of organizations and businesses operating in an area and their particular roles, however, vary both over time and from territory to territory (Robson and Robson, 1996; Sautter and Leisen, 1999). Relationships between actors vary in their levels of formality, intensity and frequency (Morrison et al., 2004; Saxena, 2005; March and Wilkinson, 2009).

Consequently, the tools used to promote and foster collaboration and the mechanisms for supporting participatory governance must also vary according to the socio-economic fabric and particular characteristics of a destination. The issues concerning coordination faced in these territories inevitably impact on the effectiveness of governance and, consequently, on whether or not a sustainable tourism model can be implemented (Bramwell and Lane, 2011). This is even more evident in multi-stakeholder contexts such as community destinations.

From a methodological perspective, however, to analyse these local networks and stakeholder dynamics it is essential to identify the stakeholders involved in the destination's tourism development and to examine their roles, their importance in the eyes of other local actors, and the intensity of the relationships that develop within a network.

The parts played by stakeholder theory and SNA are of particular interest in this process, not only because of their undoubted relevance in managerial studies, but also because of the interest in their application to tourism management studies that has been manifested, as this paper demonstrates.
Umberto Martini

Federica Buffa

Local networks,

stakeholder dynamics and

sustainability in tourism.

Opportunities and limits

in the light of stakeholder theory and SNA 
Sinergie

Vol. 33, N. 96, 2015

\section{Methodological approaches to studying multi-stakeholder systems in tourism}

\subsection{The contribution, and limitations, of stakeholder theory}

"Who really counts in an organisation?" - is one of the key questions in the debate that surrounds stakeholder theory (Freeman, 1984; Mitchell et al., 1997). The criteria and characteristics used to identify stakeholders and assess their roles and relevance can be found in studies that focus on stakeholder definition and salience (Laplume et al., 2008). Freeman's well known definition, proposed in the 1980s, has been followed by many others, which describe the characteristics and variables used to map and categorize stakeholders (Mitchell et al., 1997; Friedman and Miles, 2006). The power of a stakeholder and his/her legitimacy in the eyes of fellow actors are the characteristics most commonly used to identify and describe their roles and importance. Of particular significance is Clarkson's (1995) classification, which identifies actors who are essential to the survival of an organization as primary stakeholders, and the parameters established by Mitchell et al. (1997), which categorize stakeholders according to their importance in their relations with businesses (stakeholder salience). This importance is defined on the basis of: power, legitimacy, urgency. Highly salient stakeholders are the most significant: their power is greatest, thus legitimizing particular activities and immediately giving them the ear of other stakeholders in regard to specific issues and problems.

The models and conceptual frameworks of stakeholder theory have been increasingly used in studies on tourism management since the 1990s. Among the wide variety of subjects investigated (Bornhorst et al., 2010), many studies have focused on identifying the stakeholders in a destination (Sheehan and Ritchie, 2005; Byrd, 2007; Nilsson, 2007; Byrd et al., 2009; Currie et al., 2009), or examining in detail the role of, and the relationships within, certain categories (Robson and Robson, 1996; Sheehan et al., 2007; Gu and Ryan, 2008; Kang et al., 2008; Simpson, 2008; Stokes, 2008; d'Angella and Go, 2009). These analyses enable the mapping of stakeholders within a tourism destination, describe the collaborative/ competitive nature of their relationships and identify the most strategically significant actors. In most destinations the latter are involved in the hotel industry and/or destination management organizations - key actors in the definition of the tourist offer. The diverse connotations which actors, networks and relationships can assume, however, mean that these observations do not always hold true across destinations or over time (Timur and Getz, 2008). Moreover, there is also a notable knowledge gap regarding the roles played by the other actors involved, both directly and indirectly, in the tourism supply chain.

The qualitative approach of stakeholder theory cannot adequately reconstruct the relationship dynamics within a destination, because:

- the descriptive approach does not provide the indicators or tools needed to measure the connections between the nodes of a network and the intensity of relationships between stakeholders;

- although the definition of a stakeholder covers both individuals and 
groups $^{2}$, most studies concentrate on the roles of particular categories of actors, not realizing the fact that individual actors may have different roles or relationships, both within a particular group and across groups; - the analysis of relationships takes a focal organization as its reference point and then describes the relationships between other actors in relation to that organization. From a methodological perspective, this means that the reconstruction of a stakeholder network, and the analysis of stakeholder relationships, requires that these analyses be carried out again each time there is a particular object to be investigated.

Rowley (1997), largely prompted by this last limitation, contextualized the analysis of stakeholder relationships by introducing the concept of the network and of a possible interdependence between two or more categories of stakeholder. The network of relationships in which stakeholders are involved is wider and more complex than allowed for in the context described by the dyadic relationships between stakeholder and focal organization presented in the stakeholder model (Freeman, 1984; Donaldson and Preston, 1995) (see Figure 1). Rowley (1997) examines these concepts with regard to the indicators of centrality of social network analysis which allow a stakeholder's power to be analysed as a function of their position within a network and their links with other actors.

Fig. 1: Comparison of nodes, networks and relationships
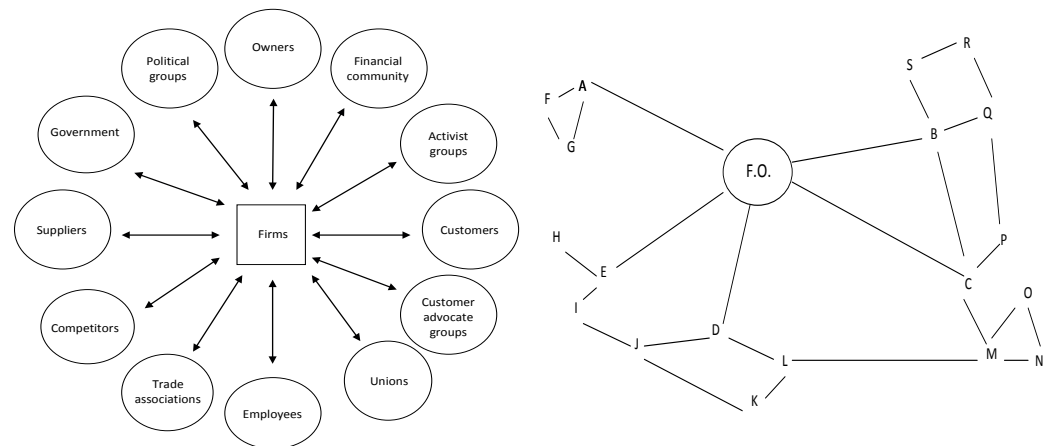

Source: own elaboration on Freeman, 1984, p. 55; Rowley, 1997, p. 891.

\subsection{The contribution and limits of social network analysis (SNA)}

SNA began to develop in the 1930s thanks to social psychologists (in primis Moreno, Lewin and Heider), Harvard anthropologists and sociologists, and Manchester anthropologists (cf Soda, 1998; Anzera, 1999; Scott, 2000; Piselli, 2001; Freeman, 2004; Trobia and Milia, 2011; Prell, 2012). Since the 1980s, SNA has been widely adopted (Borgatti and Foster, 2003;

2 Freeman (1984, p. 46) defines a stakeholder as "any group or individual who can affect or is affected by the achievement of the organization's objectives". 
sinergie Vol. 33, N. 96, 2015

Knoke and Yang, 2008). The growing complexity of economic systems and relationship contexts and the introduction of powerful software capable of detailed data analysis (eg Ucinet) has led to increased interest in SNA and in its application in many fields, including those of business economics (Anzera, 1999; Cordaz, 2007; Goyal, 2011; Trobia and Milia, 2011).

SNA observes relationships within social contexts (networks) in order to analyse the interdependence and interconnectivity between actors, groups and/or communities (Wasserman and Faust, 1994). One of the core theories of SNA is that someone's behaviour can be best understood by studying it in the context of that person's relationships. This approach is different from the perspective adopted in other studies which explain an individual's behaviour as a function of specific socio-demographic attributes and variables (Wellmann, 1988; Gulati, 1998). In SNA the latter are considered useful in that they provide an understanding of a node's or a network's context, but they are not seen as the core data (Wasserman and Faust, 1994). SNA is intended to provide a quantitative analysis of the relationships between actors by investigating network structures and the dynamics which develop within them.

With regard to the main features associated with the key elements of SNA (actors, relationships and networks) and with the best known indicators (density and centrality) it has been observed (Scott, 2000; Hannemann and Riddle; 2005, Trobia and Milia, 2011) that:

- the nodes of the network are the actors, who may be individuals, groups, organizations or even communities or aggregates. The decision-making and behaviour of actors are influenced by their relationships within a network;

- relationships are the multiple ties which connect the different nodes of a network. These are distinguished by their content (e.g., motivations, objective interests of the relationship) and form (e.g., intensity, frequency, duration, direction of the links) and connect two or more nodes, either directly or indirectly. Relationships are usually reciprocal, but their content and intensity may differ, affecting the ways in which resources are accessed and exchanged by individuals and/or subgroups;

- a network is a set of nodes and the relationships which develop within a given social context. Networks are represented by graphs which illustrate the actors and relationships by means of a series of points (nodes) and lines (ties). They may be analysed in their entirety (global network) or in part (subgroups like dyads, triads and ego-networks). Ego-networks are made up of one focal actor (ego), the set of nodes to which $(s)$ he is directly connected (alters) and any connections which develop among the alters. Star, line and circle networks are the most common network configuration.

Turning to the indicators of density and centrality (Scott, 2000; Trobia and Milia, 2011): the first expresses the degree of cohesion within a network, measuring the ratio of real to potential connections within it. Maximum density (value $=1$ ) occurs when all nodes are interconnected; its value is 0 if all nodes are isolated. Density is affected by the size of 
the network i.e. the number of nodes and connections which each actor is able to activate. The bigger the network, the more difficult it is for the actors to connect with all the other nodes. Therefore, when other variables are excluded bigger networks usually have lower density values than smaller ones. The use of the density indicator is limited by its comparability; a comparison between network densities is only significant when the networks are of the same size.

Centrality can be used both in relation to an entire network and to evaluate the position of single nodes within a network. This indicator enables an analysis of the power and relevance of the nodes and of their influence on other members of the network. The central nodes hold an advantage over the others: centrality provides easier access to resources and information as well as a greater capacity and more opportunity to influence other nodes. Among the many indicators of centrality (Freeman, 1979; Scott, 2000), Freeman's degree measures the number of relationships in which a node is involved within a network. The more relationships an actor has, the higher his/her degree of centrality. The node with the highest value enjoys an advantage over the others, since, by making use of the relationships in which it is involved, it is the least dependent on any other single node to access the resources and information it requires. Freeman's degree is particularly useful when directional relations are being used. By observing the links which each single node establishes with the other actors in the network, it is possible to determine its in-degree centrality, which provides information about the importance and prestige of an actor in relation to the other nodes, and, furthermore, allows its attributed weight to be measured.

Network centralization provides information on the distribution of centrality throughout the network, thus indicating the hierarchical degree of the network (Chiesi, 1999). Network centralization has a value of 0 when there is no disparity between the nodes (they have the same degree) and a value of $100 \%$ when the centralization is at the maximum degree (i.e. centred on a single node).

This quantitative approach alone, however, cannot fully explain and describe the context in which the resources, activities and actors are situated, or the actors' roles. In the authors' opinion this is why, from a methodological point of view, the role of SNA is to integrate and to increase the information value of the results produced by qualitative research.

The next section describes the methodology used to reconstruct a network of actors, measure the intensity of their relationships and analyse the strategic valence of stakeholders in tourist destinations through a combination of stakeholder theory and SNA.

\section{An integrated approach to studying multi-stakeholder systems in tourism: lessons from field research}

Within the field of tourism management studies the validity of SNA has been widely debated, see Scott et al. (2008), Baggio et al. (2010a); Baggio et al. (2010b) and Baggio (2011); Pforr (2006), Bhat and Milne (2008), Marzano and Scott (2009), Beritelli (2011), Beritelli and Laesser (2011),
Umberto Martini

Federica Buffa

Local networks,

stakeholder dynamics and

sustainability in tourism.

Opportunities and limits

in the light of stakeholder theory and SNA 
Sinergie Vol. 33, N. 96, 2015

Ruggieri and Iannolino (2012), use SNA to investigate the characteristics of relationships (such as power and trust) and collaboration in tourist destinations. Sciarelli and Tani (2013) also deal with relationships, proposing, from a methodological perspective, the integration of density and centrality indicators with principles and frameworks from stakeholder theory analysis. The works of Timur and Getz (2008), Presenza and Cipollina (2010) and Kimbu and Ngoasong (2013) follow a similar approach, integrating stakeholder theory with measures of centrality in order to examine key stakeholders and aspects of their relationships and coordination in the field in various destinations.

The research methodology that has been used considers the aspects that define and describe stakeholders according to stakeholder theory and uses the in-degree centrality introduced by SNA in order to $a$ ) examine the position of the actors within the destination, $b$ ) establish a criterion for distinguishing those stakeholders whose roles and significance identify them as primary stakeholders (Clarkson, 1995) or highly salient stakeholders (Mitchell et al., 1997).

Our research, carried out in two Alpine destinations, utilizes the case method. The Alps were chosen because they are a typical example of a community-type destination. The snowball sampling method - widely used in SNA - was adopted to contact research subjects.

To guarantee interviewees' privacy, detailed information about the destination cannot be included; we therefore refer to destination A and destination B. In both destinations tourism is the main economic activity and involves a multiplicity of public and private actors as well as the local community. The legal forms adopted by the DMOs of the two destinations are, however, different - a cooperative society in destination $\mathrm{A}$ and a stakeholder company in destination B - as are some features of the tourism development paths followed - strictly endogenous in destination A, more influenced by external investors in destination $\mathrm{B}$. The power imbalances among the various stakeholders reveal some important findings about networks and the relationship dynamics of community-type destinations.

The field research was conducted as follows:

1. an initial list of actors to be contacted was drawn up, containing the subjects that were identified by using the stakeholder map: they are all actors who play a significant role in the development of the destination, including DMO managers, mayors, representatives of the hospitality industry, directors of or spokespeople for important ski consortia and infrastructure, and the managers of sports centres;

2. the initial list was expanded to include people suggested by the first actors to be interviewed - each interviewee was asked to name 1-5 people whom they considered (to be) significant players in local tourism development.

Each named actor was given a degree of importance from 1 (important) to 4 (absolutely indispensable). The data was gathered during face-toface interviews or through online questionnaires sent out subsequent to contact with the person via telephone.

Following this process it was possible to reconstruct the nodes and relationships of the network, in other words the set of stakeholders who, 
through their various roles and to greater or lesser extents, contribute to the destination's tourism development.

In order to identify the most important stakeholders the value of indegree centrality, referred to the weighted adjacency matrix (a quantitative feature), and the role of the actors within the network (a qualitative feature), were jointly evaluated. The analysis of centrality identified those nodes considered to be the most important and powerful within the network. In order to identify primary and highly salient stakeholders it was necessary to establish a threshold below which nodes were no longer linked to these particular categories. This involved the evaluation of the role played by each stakeholder.

The results obtained from the calculation of in-degree centrality, combined with the qualitative analysis, contributed to the identification of the actors considered most important to the development of the destination and who, it can be presumed, are best able to attract the attention of others. Although power and legitimacy are not necessarily coincident (cf Mitchell et al., 1997), the named actors are also believed to be those generally considered to be entitled to promote and carry out activities to further the destination's tourism development.

The stakeholders whose in-degree centrality values are highest are therefore considered (to be) indispensable for the development of the destination and thus to fit the primary stakeholder profile. Their significance also recalls the power, legitimacy and urgency attributed to highly salient stakeholders.

The application of this methodology to the two case studies led to the inclusion of about $70 \%$ of the named actors, a result which allows the analysis of the network's structural features and relationship dynamics through the use of measures of centrality (Burt, 1981; Costenbader and Valente, 2003).

The nodes whose in-degree centrality value is higher than 12 are, within both destinations, stakeholders in positions of particular importance. Most of them have more than one function and are involved in both private enterprises and public administration. The importance of the public-private dialectic in both territories (cf section 2) is confirmed by an examination of the stakeholders with the highest in-degree centrality values. They are representatives of DMOs and of government bodies and the manager of an important ski lift company in destination $\mathrm{A}$ and that of a local bank in destination $\mathrm{B}$. The importance accorded to these stakeholders by the other actors in the network and the evaluation of their position through the centrality indicator singles out these actors as indispensable for the development of the territory and distinguishes them as primary stakeholders and highly salient stakeholders.

The adoption of the in-degree network centralization reveals two different situations. In destination $\mathrm{A}$ this value is equal to $40.4 \%$; in destination B to $26.4 \%$. Although in neither case do we find a star network (value $=100 \%$ ), or a circle network (value $=0$ ), in the first case we find a greater concentration of power in some of the nodes and in the second case there is greater homogeneity. Seen on a graph, this is due to the more central position of the primary stakeholders in destination $\mathrm{A}$ in comparison to those in destination B (see Figure 2). 


\section{sinergie}

italian journal of management Vol. 33, N. 96, 2015
Fig. 2: Comparison of networks, nodes and primary stakeholders

DESTINATION A

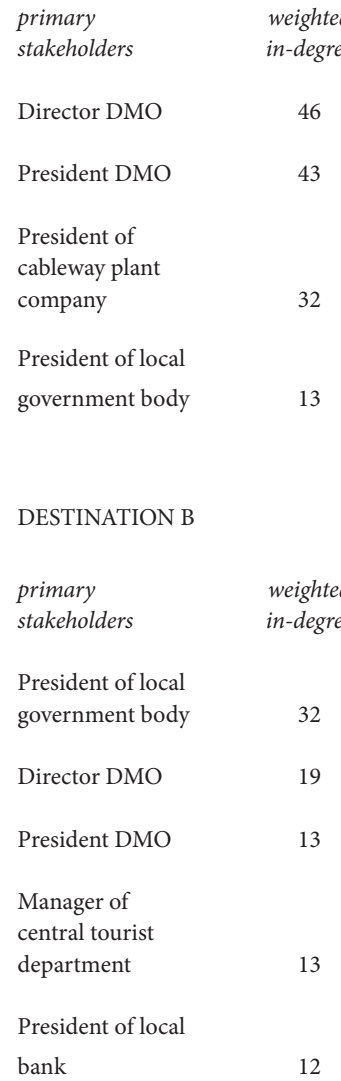

Source: own elaboration

\section{Conclusions}

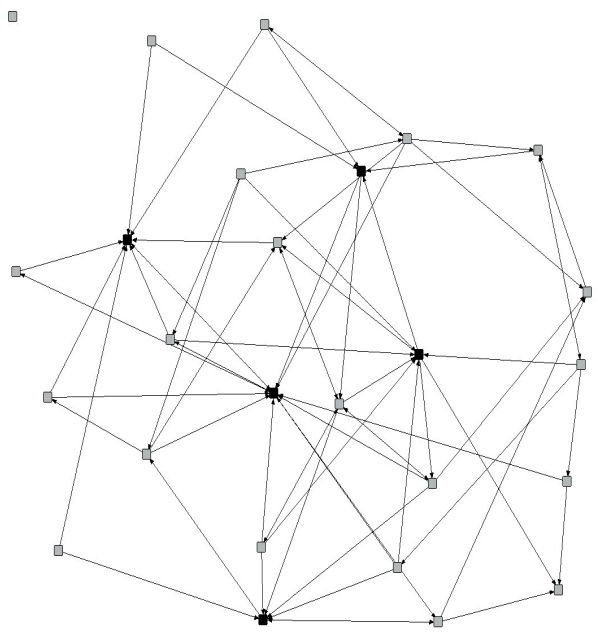

This paper illustrates the methodology adopted to reconstruct a stakeholder map and to identify those who, according to their position within the network, play a key role in its functioning. These analyses also examine features that are pertinent to the power associated with the actors and to how this is distributed within the network. The integration of qualitative and quantitative approaches allows the use of an original method to reconstruct the web of relationships that characterizes multistakeholder territorial systems of which tourism destinations are a typical example. This methodology transcends the limitations of the qualitative approach which only refers to one focal organisation (Rowley, 1997), allowing the reconstruction of a network of actors and the complex web of their relationships. 
Regarding the analyses carried out in the destination communities, the use of some SNA indicators complements the analysis perspective of stakeholder theory by revealing the positions of the nodes in the network and identifying those with the most power. The analysis of in-degree network centralization also picked up the homogeneity, or rather the disparity, between different actors' positions, scrutinizing the characteristics which explain the distribution of power in the destination.

As shown in the first part of the paper, the tourism offer in these territories is a function of the level of collaboration and coordination between the actors involved. The problems associated with the governance and management of these multi-stakeholder systems can be mitigated by adopting models of community participation and public-private partnerships which can enable the coordination of numerous actors, all operating autonomously. Within this debate the identification of primary stakeholders is considered to be of particular importance since it allows the nodes which represent key actors in the destination's development to be analysed. This analysis enables the identification of those considered to be most powerful and capable of taking a leading role in the coordination and collaboration required for further territorial development.

The identification of primary stakeholders can also contribute to the examination of the dynamics and characteristics of relationships with regard to aspects concerning destination governance (revealing, for example, questions concerning the involvement of the local community, government bodies, the DMO, local or external firms), and to an understanding of matters that are fundamental in increasing interconnections between different actors (e.g. trust).

Such an analysis allows us to identify the nodes within a community that are capable of conveying information, influencing behaviours and decision-making, governing effectively and taking political action in order to foster the sustainability of the destination's tourism development. The reconstruction of networks within territories and the identification of their respective nodes provide a sounder basis for deciding strategies and instruments to facilitate processes of participative governance in accordance with principles of sustainability.

Given the generally accepted hypothesis that the sustainability of a destination's tourist offer is correlated with the existence of a collective decision-making process which takes into account the different objectives of the actors involved, the analytical tool provided by SNA can open up new perspectives in the field of destination management by classifying and specifying the importance of relationships and providing a useful key for the identification of the forms and functions of territorial coordination bodies.

\section{References}

AHN BY., LEE BK., SHAFER CS. (2002), “Operationalizing sustainability in regional tourism planning", Tourism Management, vol. 23, n. 1, pp. 1-15.

ANZERA G. (1999), L'analisi dei reticoli sociali, Euroma, Roma.

BAGGIO R. (2011), "Collaboration and cooperation in a tourism destination", Current Issues in Tourism, vol. 14, n. 2, pp. 183-189. 


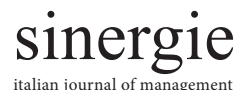
Vol. 33, N. 96, 2015

BAGGIO R., SCOTT N., COOPER C. (2010a), "Improving tourism destination governance”, Tourism Review, vol. 65, n. 4, pp. 51-60.

BAGGIO R., SCOTT N., COOPER C. (2010b), "Network science - a review with a focus on tourism", Annals of Tourism Research, vol. 37, n. 3, pp. 802-827.

BERITELLI P. (2011), "Cooperation among prominent actors in a tourist destination”, Annals of Tourism Research, vol. 38, n. 2, pp. 607-629.

BERITELLI P., LAESSER C. (2011), "Power dimensions and influence reputation in tourist destinations", Tourism Management, vol. 32, n. 6, pp. 1299-1309.

BHAT S.S., MILNE S. (2008), "Network effects on cooperation in destination website development", Tourism Management, vol. 29, n. 6, pp. 1131-1140.

BORGATTI S.P., FOSTER P.C. (2003), "The Network Paradigm in Organizational Research", Journal of Management, vol. 29, n. 6, pp. 991-1013.

BORNHORST T., RITCHIE J.R.B, SHEEHAN L. (2010), "Determinants of tourism success for DMOs \& destinations", Tourism Management, vol. 31, n. 5, pp. 572-589.

BRAMWELL B., LANE, B. (1993), "Sustainable tourism”, Journal of Sustainable Tourism, vol. 1, n. 1, pp. 1-5.

BRAMWELL B., LANE B. (2000) (Eds.), Tourism collaboration and partnerships, Channel View Publications, Clevedon.

BRAMWELL B., LANE B. (2011), "Critical research on the governance of tourism and sustainability", Journal of Sustainable Tourism, vol. 19, n. 4-5, pp. 411421.

BRAMWELL B., SHARMAN A. (1999), "Collaboration in local tourism policymaking”, Annals of Tourism Research, vol. 26, n. 2, pp. 392-415.

BYRD E.T. (2007), "Stakeholders in sustainable tourism development and their roles", Tourism Review, vol. 62, n. 2, pp. 6-13.

BYRD E.T., BOSLEY H.E., DRONBERGER M.G. (2009), "Comparison of stakeholder perceptions of tourism impacts in rural eastern North Carolina", Tourism Management, vol. 30, n. 5, pp. 693-703.

BURT R.S. (1981), "Studying status/role-sets as ersatz network position in mass surveys", Sociological Methods and Research, vol. 9, n. 3, pp. 313-337.

CATER E. (1993), "Ecotourism in the Third Word", Tourism Management, vol. 14 , n. 1, pp. 85-90.

CHIESI A.M. (1999), Lanalisi dei reticoli sociali, Franco Angeli, Milano.

CLARKSON M.B. (1995), "A Stakeholder Framework for Analyzing and Evaluating Corporate Social Performance", Academy of Management Review, vol. 20, n. 1, pp. 92-117.

CORDAZ D. (2007), "Lessico delle reti", in Salvini A. (A cura di), Analisi delle reti sociali. Teorie, metodi, applicazioni, Franco Angeli, Milano.

CRONIN L. (1990), "A strategy for tourism and sustainable development", World Leisure and Recreation, vol. 32, n. 3, pp. 12-18.

CROUCHG.I.,(2007), Modellingdestinationcompetitiveness, Cooperative Research Centre for Sustainable Tourism (AU), www.sustainabletourismonline. com/awms/Upload/Resource/bookshop/Crouch_modelDestnCompweb.pdf.

COSTENBADER E., VALENTE T.W. (2003), "The stability of centrality measures when networks are sampled”, Social Networks, vol. 25, n. 4, pp. 283-307.

CURRIE R., SEATON R., WESLEY F. (2009), "Determining stakeholders for feasibility analysis”, Annals of Tourism Research, vol. 36, n. 1, pp. 41-63. 
D’ANGELLA F., GO F.M. (2009), “Tale of two cities' collaborative tourism marketing”, Tourism Management, vol. 30, n. 3, pp. 429-440.

DONALDSON T., PRESTON L.E. (1995), "The Stakeholder Theory of the Corporation", Academy of Management Review, vol. 20, n. 1, pp. 65-92.

DREDGE D. (2006), "Policy networks and the local organisation of tourism”, Tourism Management, vol. 27, n. 2, pp. 269-280.

DWYER L., EDWARDS D., MISTILIS N., ROMAN C., SCOTT N. (2009), "Destination and enterprise management for a tourism future", Tourism Management, vol. 30, n. 1, pp. 63-74.

FREEMAN L.C. (1979), “Centrality in Social Networks", Social Networks, vol. 1, n. 3, pp. 215-239.

FREEMAN L.C. (2004), The development of social network analysis, Empirical Press, Vancouver.

FREEMAN R.E. (1984), A stakeholder approach to strategic management, Pitman, Boston.

FRIEDMAN A.L., MILES S. (2006), Stakeholders. Theory and Practice, Oxford University Press, New York.

GARROD B., FYALL A. (1998), "Beyond the rhetoric of sustainable tourism?", Tourism Management, vol. 19, n. 3, pp. 199-212.

GETZ D. (1986), "Models in tourism planning", Tourism Management, vol. 7, n. 1, pp. 21-32.

GLADWIN T.N., KENNELLY J.J., KRAUSE T.S. (1995), "Shifting paradigms for sustainable development: Implications for management theory and research", The Academy of Management Review, vol. 20, n. 4, pp. 874-907.

GOYAL S. (2011), "Social Networks in Economics", in Scott J., Carrington P.J. (Eds.), The Sage Handbook of Social Network Analysis, Sage, London.

GU H., RYAN C. (2008), "Place attachment, identity and community impacts of tourism", Tourism Management, vol. 29, n. 4, pp. 637-647.

GULATI R. (1998), "Alliances and networks", Strategic Management Journal, vol. 19, n. 4, pp. 293-317.

HALL C.M. (1994), Tourism and Politics, John Wiley, Chichester.

HALL C.M. (1999), "Rethinking collaboration and partnership", Journal of Sustainable Tourism, vol. 7, n. 3-4, pp. 274-289.

HALL C.M. (2011), "A typology of governance and its implications for tourism policy analysis", Journal of Sustainable Tourism, vol. 19, n. 4-5, pp. 437-457.

HALL C.M., JENKINS J.M. (1995), Tourism and public policy, Routledge, London.

HANNEMAN R.A., RIDDLE M. (2005), Introduction to social network methods, University of California, Riverside, available at http://faculty.ucr. edu/ hanneman

HARDY A., BEETON R.J.S., PEARSON L. (2002), "Sustainable tourism”, Journal of Sustainable Tourism, vol. 10, n. 6, pp. 475-496.

HAYWOOD K.M. (1988), "Responsible and responsive tourism planning in the community", Tourism Management, vol. 9, n. 2, pp. 105-118.

HJALAGER A.M. (1996), “Tourism and the environment”, Journal of Sustainable Tourism, vol. 4, n. 4, pp. 201-218.

HUGHES G. (1995), “The cultural construction of tourism”, Tourism Management, vol. 16, n. 1, pp. 65-78.

HUNTER C. (1995), "On the need to re-conceptualise sustainable tourism development”, Journal of Sustainable Tourism, vol. 3, n. 3, pp. 155-165.
Umberto Martini

Federica Buffa

Local networks,

stakeholder dynamics and

sustainability in tourism.

Opportunities and limits

in the light of stakeholder theory and SNA 
Sinergie Vol. 33, N. 96, 2015

HUNTER C. (1997), "Sustainable tourism as an adaptive paradigm", Annals of Tourism Research, vol. 24, n. 4, pp. 850-867.

HUNTER C., GREEN H. (1995), Tourism and Environment, Routledge, London.

INSKEEP E. (1997), Tourism Planning, Van Nostrand Reinhold, New York.

JAMAL T., GETZ D. (1995), "Collaboration theory and community tourism planning”, Annals of Tourism Research, vol. 22, n. 1, pp. 186-204.

KANG S.K., LEEB C.K., YOON Y., LONG P.T. (2008), "Resident perception of the impact of limited-stakes community-based casino gaming in mature gaming communities", Tourism Management, vol. 29, n. 4, pp. 681-694.

KIMBU A.N., NGOASONG M.Z. (2013), "Centralised decentralisation of tourism development", Annals of Tourism Research, vol. 40, n. 1, pp. 235259.

KNOKE D., YANG S. (2008), Social Network Analysis, Sage, Thousand Oaks.

LANE B. (1994), "Sustainable rural tourism strategies", Journal of Sustainable Tourism, vol. 2, n. 1-2, pp. 102-111.

LAPLUME A.O., SONPAR K., LITZ R.A. (2008), "Stakeholder Theory”, Journal of Management, vol. 34, n. 6, pp. 1152-1189.

MARCH R., WILKINSON I. (2009). "Conceptual tools for evaluating tourism partnerships", Tourism Management, vol. 30, n. 3, pp. 455-462.

MARZANO G., SCOTT N. (2009), "Power in destination branding", Annals of Tourism Research, vol. 36, n. 2, pp.247-267.

MAZANEC J.A., WOEBER K., ZINS A.H. (2007), “Tourism destination competitiveness", Journal of Travel Research, vol. 46, n. 1, pp. 86-95.

MIDDLETON V.T.C, HAWKINS R. (1998), Sustainable Tourism, ButterworthHeinemann, Oxford.

MIHALIC T. (2000), "Environmental management of a tourist destination", Tourism Management, vol. 21, n. 1, pp. 65-78.

MILNE S., ATELJEVIC I. (2001), "Tourism, economic development and the global-local nexus", Tourism Geographies, vol. 3, n. 4, pp. 369-393.

MITCHELL R.K., AGLE B.R., WOOD D.J. (1997), "Toward a Theory of Stakeholder Identification and Salience", The Academy of Management Review, vol. 22, n. 4, pp. 853-886.

MORRISON A., LYNCH P., JOHNS N. (2004). "International tourism networks", International Journal of Contemporary Hospitality Management, vol. 16, n. 3, pp. 197-202.

NILSSON P.Å. (2007), "Stakeholder Theory: The Need for a Convenor", Scandinavian Journal of Hospitality and Tourism, vol. 7, n. 2, pp. 171-184.

PFORR C. (2006), "Tourism policy in the making”, Annals of Tourism Research, vol. 33, n. 1, pp. 87-108.

PISELLI F. (2001), "Reti sociali e comunicative", in Piselli F. (a cura di), Reti. L'analisi di network nelle scienze sociali, Donzelli, Roma.

PRELL C. (2012), Social Network Analysis, Sage, London.

PRESENZA A., CIPOLLINA M. (2010), "Analyzing tourism stakeholders networks", Tourism Review, vol. 65, n. 4, pp. 17-30.

REED M.G. (1997), "Power relations and community-based tourism planning", Annals of Tourism Research, vol. 24, n. 3, pp. 566-591.

REID D.G., MAIR H., GEORGE W. (2004), "Community tourism planning", Annals of Tourism Research, vol. 31, n. 3, pp. 623-639. 
RITCHIE J.R.B., CROUCH G.I. (2000), “The competitive destination”, Tourism Management, vol. 21, n. 1, pp. 1-7.

RITCHIE J.R.B., CROUCH G.I. (2005), The Competitive Destination, CABI Publishing, Oxon.

ROBSON J., ROBSON I. (1996), "From shareholders to stakeholders", Tourism Management, vol. 17, n. 7, pp. 533-540.

ROWLEY T.J. (1997), "Moving beyond dyadic ties", The Academy of Management Review, vol. 22, n. 4, pp. 887-910.

RUGGIERI G., IANNOLINO S. (2012), "Tourism destination and the role of trust", in Morvillo A. (Ed.), Advances in Tourism Studies, McGraw-Hill, Milano.

RYAN C. (2002), "Equity, management, power sharing and sustainability", Tourism Management, vol. 23, n. 1, pp. 17-26.

SAUTTER E.T., LEISEN B. (1999), "Managing stakeholders", Annals of Tourism Research, vol. 26, n. 2, pp. 312-328.

SAXENA G. (2005), "Relationships, networks and the learning regions", Tourism Management, vol. 26, n. 2, pp. 277-289.

SCIARELLI M., TANI M. (2013), "Network Approach and Stakeholder Management", Business System Review, vol. 2, n. 2, pp. 175-190.

SCOTT J. (2000), Social Network Analysis, Sage, London.

SCOTT N., COOPER C., BAGGIO R. (2008), "Destination networks", Annals of Tourism Research, vol. 35, n. 1, pp. 169-188.

SHARPLEY R. (2000), “Tourism and sustainable development", Journal of Sustainable Tourism, vol. 8, n. 1, pp. 1-19.

SHEEHAN L.R., RITCHIE J.R.B. (2005), "Destination stakeholders", Annals of Tourism Research, vol. 32, n. 3, pp. 711-734.

SHEEHAN L.R., RITCHIE J.R.B., HUDSON S. (2007), “The Destination Promotion Triad", Journal of Travel Research, vol. 46, n. 1, pp. 64-74.

SIMMONS D.G. (1994), "Community participation in tourism planning", Tourism Management, vol. 15, n. 2, pp. 98-108.

SIMPSON M.C. (2008). "Community Benefit Tourism Initiatives - A conceptual oxymoron?”, Tourism Management, vol. 29, n. 1, pp. 1-18.

SODA G. (1998), Reti tra imprese, Carocci, Roma.

STOKES R. (2008), "Tourism strategy making: Insights to the events tourism domain", Tourism Management, vol. 29, n. 2, pp. 252-262.

SWARBROOKE J. (1999), Sustainable Tourism Management, CABI, Wallingford.

TIMUR S., GETZ D. (2008), "A network perspective on managing stakeholders for sustainable urban tourism", International Journal of Contemporary Hospitality Management, vol. 20, n. 4, pp. 445-461.

TROBIA A., MILIA V. (2011), Social network analysis, Carocci, Roma.

TURNER R.K., PEARCE D., BATEMAN I. (1994), Environmental Economics, Harvester Wheatsheaf, Hemel Hemstead.

UNWTO (2011), Algarve Forum on Tourism and Science, Vilamoura, Algarve (Portugal), 1-3 June 2011, Executive conclusion Papers http://know.unwto. org/en/event/unwto-knowledge-network-algarve-forum.

UNWTO - UNEP (2005), Making Tourism More Sustainable, www.unep.fr/shared/ publications/pdf/DTIx0592xPA-TourismPolicyEN.pdf.

WASSERMAN S., FAUST K. (1994), Social network analysis, Cambridge University Press, Cambridge.
Umberto Martini Federica Buffa Local networks

stakeholder dynamics and

sustainability in tourism.

Opportunities and limits

in the light of stakeholder theory and SNA 
sinergie

italian journal of managent Vol. 33, N. 96, 2015

WEAVER D.B. (2011), "Organic, incremental and induced paths to sustainable mass tourism convergence", Tourism Management, vol. 30, n. 1, pp. 1-8.

WELLMANN B. (1988), "Structural Analysis", in Wellman B., Berkowitz S.D. (Eds.), Social Structure, Cambridge University Press, Cambridge.

\section{Academic or professional position and contacts}

\section{Umberto Martini}

Full Professor in Economics and Business Management

University of Trento, Italy

e-mail: umberto.martini@unitn.it

\section{Federica Buffa}

Assistant Professor in Economics and Business Management

University of Trento, Italy

e-mail: federica.buffa@unitn.it

sinergie italian journal of management

ISSN 0393-5108 DOI 10.7433/s96.2015.07 pp. 113-130

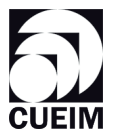

